\title{
IMPACT OF AQUAFAT-O ${ }^{\circledR}$ ON GROWTH PERFORMANCE, FEED UTILIZATION, CHEMICAL COMPOSITION AND ECONOMIC EFFICIENCY OF ADULT NILE TILAPIA, Oreochromis niloticus \\ Khalil, F. F ; A. A. Gabr ; M. M. Refaey and M. A. Al Samarae \\ Animal Production, Dept. Fac. of Agric., Mansoura University, Egypt.
}

\begin{abstract}
The aims of the present study were to assess the effects of the replacement graded levels of aquafat- ${ }^{\circledR}(0,1,2$ and $3 \%)$ instead of corn oil on the growth performance, feed and nutrients utilization, chemical composition of the whole fish body and the economic efficiency of adult Nile tilapia Oreochromis niloticus,( females and the males) for 11 weeks. The obtained results showed the replacement of aquafat $-\mathrm{O}^{\circledR}$ at a level of $1 \%$ for adult $O$. niloticus, females and males significantly $(P$ $\leq 0.05$ ) enhanced fish growth, feed intake and nutrients utilization, as well as realized slight improving of chemical composition of the whole fish body and economic efficiency. Hence, it could be concluded that replacement of aquafat- $\mathrm{O}^{\circledR}$ at a level $1 \%$ of corn oil led to improvement of productive performance and economic efficiency of the adult females and males Nile tilapia (O. niloticus). It so may be using of aquafat- $\mathrm{O}^{\circledR}$ as a growth promoter in fish farming and hatcheries.
\end{abstract}

Keywords: Nile tilapia - aquafat- ${ }^{\circledR}$ - growth performance - economic efficiency.

\section{INTRODUCTION}

Nile tilapia, Oreochromis niloticus, has become one of the most commonly farmed freshwater fish species throughout the world (Beveridge and McAndrew 2000). Tilapia species constitute a major and important item in the Egyptian fish farming. It show many favorable attributes as culture species, on the basis of its general hardness, high yield potential, resistance to diseases, ability to grow on a wide range of natural and cheap artificial foods, Also can with stand low oxygen concentrations, tolerate the worst ecological conditions, overcrowding and a wide range of salinities and still produce a highly acceptable flesh (El-Sayed, 2006). Therefore, tilapias are the second specie offer carps as the most widely farmed freshwater $r$ fish in the world (FAO, 2010). In Egypt, the total production of tilapia fish was 738.64 thousand tons in 2013 , which consider as approximately $50-79 \%$ of the total fish production (GAFRD, 2013).

Food availability and favorable feeding might have important effects on the energy needed in somatic growth and reproduction of fish. These factors may lead to early maturing of individuals, resulting in the production of more gametes because of the improved metabolism and surplus energy (Wootton, 1990). So, brood stock nutrition is recognized as a major factor that can influence fish reproduction and subsequent larval quality of many fish species (Izquierdo et al., 2001). It is well known that lipids, especially the dietary essential fatty acid content play an important role in the improvement of egg and fry quality (Sink and Lochmann, 2008). It is required in the energy 
production processes in the animal tissues and function as carriers of certain non-fat nutrients such as fat soluble vitamin $A, D$ and $K$ (Watanabe, 1982). The specific requirement of the dietary essential fatty acid usually differs considerably from species to species. Generally, for freshwater fish as shown by reproductive study conducted on Nile tilapia, the brood stocks require higher content of $n-6$ fatty acid in the diets to realize an improvement on the number of female spawning, spawning frequency and number of fry per spawning (Watanabe, 1982). This may suggest that tilapia would utilize plant oils (rich in n-6 fatty acids) more efficiently than fish oils (rich in n-3 fatty acids) (El-Sayed, 2006). Therefore, the aim of the current study was to assess the effects of replacement of aquafat $-{ }^{\circledR}$ instead of corn oil the diet of adult Nile tilapia female and male on growth performance, feed utilization, chemical composition of whole fish body and economic efficiency for 11 week (experimental period).

\section{MATERIALS AND METHODS}

The experimental management:

This study was carried out in Fish Research Unit, Faculty of Agriculture, Mansoura University, Al-Dakahlia governorate, Egypt. Adult female and male Nile tilapia $O$. niloticus, with an average initial body weight $56.8 \pm 0.30$ and $75.8 \pm 0.50 \mathrm{~g}$, for female and male respectively, which were purchased from a private farm in Kafr Elsheikh governorate, Egypt. Fish were stocked in rearing tanks for two weeks as an adaptation period, and fed on ( table1) during this period.

A total of 480 fish (females and males 240 each) were distributed separately and divided into eight experimental treatments (three replicates per treatment). The design of the experiment was shown in Table (1). Fish were stocked at $20 \mathrm{fish} /$ per tank $\left(1 \mathrm{~m}^{3}\right.$ in volume) which was constructed with an upper irrigation open, an under drainage, an air stone connected with electric compressor. Fresh underground water was used to change one third of the water in each tank three times a week.

Table (1): Design of the experimental treatments

\begin{tabular}{|c|c|}
\hline Treat. & Design \\
\hline $\mathrm{T}_{1}, \mathrm{q}$ & Basal ration (BR) contain $5 \%$ corn oil (as a control) \\
\hline $\mathrm{T}_{2}, \mathrm{P}$ & $(\mathrm{BR})$ contains $4 \%$ corn oil $+1 \%$ Aquafat-O \\
\hline $\mathrm{T}_{3}, \mathrm{q}$ & (BR) contains $3 \%$ corn oil $+2 \%$ Aquafat-O \\
\hline $\mathrm{T}_{4}, \mathrm{P}$ & (BR) contains $2 \%$ corn oil $+3 \%$ Aquafat-O \\
\hline$T_{5}, \hat{0}$ & (BR) contain 5\% corn oil (as a control) \\
\hline $\mathrm{T}_{6}, \hat{\mathrm{O}}$ & (BR) contains $4 \%$ corn oil $+1 \%$ Aquafat-O \\
\hline $\mathrm{T}_{7}, \hat{0}$ & (BR) contains $3 \%$ corn oil $+2 \%$ Aquafat-O \\
\hline$T_{8}, \hat{0}$ & (BR) contains $2 \%$ corn oil $+3 \%$ Aquafat-O \\
\hline
\end{tabular}

Aquafat- $O^{\circledR}$ contained calcium salt of linoleic acid, oleic acid, linolenic acid, palm fatty acids distillate (PFAD) and fish oil, which manufactured by Norel-Misr, www.norel.es. The aquafat- ${ }^{\circledR}$ formula was comprised of crude 
fat $84 \%$, ash $12.5 \%$ calcium (included in ash) $8 \%$ moisture $3.5 \%$ and $\mathrm{BHT}$ $0.01 \%$ (Anti-oxidant). The Aquafat- ${ }^{\circledR}$ contains $64.2 \%$ unsaturated fatty acids and $35.8 \%$ saturated fatty acids, which showed in (Table 2 ).

Table (2): Fatty acid composition of Aquafat- ${ }^{\circledR}$ determined by NorelMisr company

\begin{tabular}{|l|c|}
\hline Fatty acids & $\mathbf{( \% )}$ \\
\hline \multicolumn{2}{|c|}{ Saturated fatty acids } \\
\hline Myristic acid (C14:0) & 1.4 \\
\hline Palmitic acid (C16:0) & 30.1 \\
\hline Stearic acid (C18:0) & 4.3 \\
\hline Total & 35.8 \\
\hline \multicolumn{2}{|c|}{ Unsaturated fatty acids } \\
\hline Palmitolic acid (C16:1) & 0.8 \\
\hline Oleic acid (C18:1) & 37.75 \\
\hline Linoleic acid (C18:2) & 19 \\
\hline Linolenic acid (C18:3) & 6.65 \\
\hline Total & 64.2 \\
\hline
\end{tabular}

Ingredients of the experimental basal ration (BR) were bought from the local market and proximate chemical analysis was carried out according to AOAC (2000), as shown in Table 3. The commercial diet was ground then corn oil ( $5 \%$ in diet) was replaced by aquafat- ${ }^{\circledR}$ at levels of $0,1,2$, and 3 $\%$ of corn oil, and all diets were milled and mixed, then pressed by manufacturing machine (pellets size $1 \mathrm{~mm}$ ). During the experiment fish fed the experimental diets at a rate of $4 \%$ of their live body weight daily, six days a week during the first 4 weeks, then at $3 \%$ during the following 4 weeks and at $2 \%$ until the end of the experiment. Experimental diets were introduced by hand three times at 8 a.m., 12.00 p.m. and 15.00 p.m.

Water quality parameters in each tank were measured weekly, including temperature (via a thermometer), pH-value (using Jenway Ltd., Model 350-pH-meter, Staffordshire ST15 0SA, UK) and dissolved oxygen (using Jenway Ltd., Model 970-dissolved oxygen meter, Staffordshire ST15 OSA, UK). Average values of water temperature were $26.0 \pm 0.8 \mathrm{C}, \mathrm{pH} 8.19 \pm$ 0.2 and dissolved oxygen $7.21 \pm 0.3 \mathrm{mg} / \mathrm{L}$. Light was controlled by a timer to provide $14 \mathrm{~h}$ light: and $10 \mathrm{~h}$ darkness as an immaculate imitation to actual light-darkness durations 
Table (3): Formulation and the chemical analysis of experimental diets (\% on dry matter basis )

\begin{tabular}{|c|c|c|c|c|}
\hline Ingredients & Diet 1 & Diet 2 & Diet 3 & Diet 4 \\
\hline Fish meal $(70 \%)$ (CP) & 10 & 10 & 10 & 10 \\
\hline Corn Gluten $(60 \%)(\mathrm{CP})$ & 12 & 12 & 12 & 12 \\
\hline Soybean meal (44\%) (CP) & 28 & 28 & 28 & 28 \\
\hline Yellow corn & 20 & 20 & 20 & 20 \\
\hline Rice bran & 20 & 20 & 20 & 20 \\
\hline Corn Oil & 5 & 4 & 3 & 2 \\
\hline Aquafat- ${ }^{\circledR}$ & 0 & 1 & 2 & 3 \\
\hline Molasses & 4 & 4 & 4 & 4 \\
\hline Premix $^{a}$ & 1 & 1 & 1 & 1 \\
\hline \multicolumn{5}{|l|}{ Chemical composition (\%) } \\
\hline Dry matter (DM) & 89.99 & 90.34 & 90.97 & 90.05 \\
\hline Crude protein (CP) & 33.20 & 32.80 & 33.05 & 33.30 \\
\hline Ether extract (EE) & 7.00 & 7.71 & 7.84 & 7.50 \\
\hline Ash & 5.32 & 5.58 & 5.79 & 5.76 \\
\hline Nitrogen free extract (NFE) & 54.48 & 53.91 & 53.32 & 53.44 \\
\hline Gross energy (Kcal/100 g DM) (GE) ${ }^{\mathrm{b}}$ & 477.2 & 479.3 & 479.6 & 478.3 \\
\hline Metabolizable energy (ME) (kcal/100g DM) ${ }^{c}$ & 395.1 & 397.1 & 397.2 & 396 \\
\hline Protein/energy $(P / E)$ ratio (mg CP/Kcal GE) ${ }^{d}$ & 69.57 & 68.43 & 68.92 & 69.63 \\
\hline
\end{tabular}

${ }^{a}$ Each $1 \mathrm{~kg}$ premix contains : Vit. A, 12000,000 IU; Vit. E, 10,000 mg; Vit. K3, 3000 mg; Vit. D3, 3000,000 IU; Vit. B1 200 mg; Vit. B2, 5000 mg; Vit. B6, 3000 mg; Vit. B12, 15 mg; Folic acid $1000 \mathrm{mg}$; Nicotinic acid $35000 \mathrm{mg}$; Biotin, $50 \mathrm{mg}$; Pantothenic acid 10,000 mg; Mn 80g; Cu 8.8g; Zn $70 \mathrm{~g}$; Fe $35 \mathrm{~g}$; I 1g; Co 0.15g and Se 0.3g.

${ }^{\mathrm{b}} \mathrm{GE}(\mathrm{kcal} / 100 \mathrm{~g} \mathrm{DM})=(\mathrm{CP} \times 5.64)+(\mathrm{EE} \times 9.44)+($ Total carbohydrates $\times 4.11)$ calculated according to NRC (1993).

${ }^{\mathrm{c}} \mathrm{ME}(\mathrm{kcal} / 100 \mathrm{~g} \mathrm{DM})=$ Metabolizable energy was calculated by using factors $3.49,8.10$ and $4.50 \mathrm{kcal} / \mathrm{g}$ for NFE, EE and CP, respectively according to Pantha (1982).

${ }^{\mathrm{d}} \mathrm{P} / \mathrm{E}$ ratio $(\mathrm{mg}$ protein/kcal gross energy) $=\mathrm{CP} / \mathrm{GE} \times 1000$.

Fish sampling and performance parameters:

At the start and at the end of the experiment, fish samples were collected and kept frozen till the chemical analysis of the whole fish body according to AOAC (2000). Gross energy content in the experimental fish was calculated according to NRC (1993), being 9.44 and $5.64 \mathrm{kcal} / \mathrm{g}$ for EE and $\mathrm{CP}$, respectively.

Growth performance parameters of adult $O$. niloticus females and males including total weight gain (AWG), average daily gain (ADG), relative growth rate \% (RGR), specific growth rate \%/day (SGR) and survival rate \% (SR) were calculated. Also, feed utilization parameters were calculated such as, feed conversion ratio (FCR), protein efficiency ratio (PER), protein productive value \% (PPV) and energy utilization \% (EU).

\section{Economical Evaluation}

The cost of feed required to produce a unit of fish biomass was estimated using a simple economic analysis. The estimation was based on local retail sale market price of all the dietary ingredients at the time of the study. These prices (in LE/kg) were as follows: fish meal, 10.60; corn gluten, 
7.40; soybean meal, 4.45; yellow corn, 1.90; wheat bran 2.50; corn oil 11.00; vitamin and mineral premix,10.0; molasses, 6.00 and aquafat- ${ }^{\circledR}, 6.00 \mathrm{LE} / \mathrm{Kg}$. Statistical analysis:

The obtained data for females and males were statistically analyzed using general linear models (GLM) procedure according to SAS (2001) for users guide. All ratios and percentages were arcsine-transformed prior to statistical analyses. The differences between means of treatments were compared for the significance $(P \leq 0.05)$ using Duncan's multiple rang test (Duncan, 1955), as described by Bailey (1995) .

\section{RESULTS}

\section{Growth performance parameters:}

Growth performance parameters (FW, TWG, ADG, RGR and SGR) of adult females and males of Nile tilapia illustrated in Table (4), which revealed that $1 \%$ of aquafat $-\mathrm{O}^{\circledR}\left(\mathrm{T}_{2}\right.$ and $\mathrm{T}_{6}$, ) was the highest values in all growth performance parameters compared with other treatments. While, the control group gave the lowest values of all growth performance in females and males. In females, no significant $(P \leq 0.05)$ differences between $T_{3}$ and $T_{4}(2$ and $3 \%$ aquafat- ${ }^{\circledR}$, respectively) were recorded, but in males the higher values was obtained in $\mathrm{T}_{7}$ as compared with $\mathrm{T}_{8}(3 \%)$. Furthermore, the survival rate was ranged between 95 and $100 \%$ in the females and males, and no significant $(P \leq 0.05)$ differences among treatments.

Table (4): Effect of replacing aquafat- $O^{\circledR}$ in the diet on growth performance parameters of the adult Nile tilapia females and males

\begin{tabular}{|c|c|c|c|c|c|c|}
\hline Treat. & FW (g) & TWG (g) & $\begin{array}{c}\text { ADG } \\
\text { (g / fish / day) }\end{array}$ & $\begin{array}{c}\text { RGR } \\
(\%)\end{array}$ & $\begin{array}{c}\text { SGR } \\
\text { (\%/day) }\end{array}$ & $\begin{array}{l}\text { SR } \\
(\%)\end{array}$ \\
\hline \multicolumn{7}{|c|}{ Female } \\
\hline $\mathrm{T}_{1}$ & $117.2^{\mathrm{C}}$ & $60.70^{C}$ & $0.78^{\mathrm{C}}$ & $107.4^{\mathrm{C}}$ & $0.94^{c}$ & 100 \\
\hline $\mathrm{T}_{2}$ & $143.1^{\mathrm{a}}$ & $86.30^{a}$ & $1.12^{\mathrm{a}}$ & $151.6^{\mathrm{a}}$ & $1.19^{\mathrm{a}}$ & 95 \\
\hline $\mathrm{T}_{3}$ & $131.5^{b}$ & $74.53^{b}$ & $0.96^{b}$ & $130.7^{\mathrm{b}}$ & $1.08^{\mathrm{b}}$ & 100 \\
\hline $\mathrm{T}_{4}$ & $132.5^{\mathrm{D}}$ & $75.86^{\mathrm{D}}$ & $0.98^{D}$ & $133.9^{\mathrm{D}}$ & $1.10^{\mathrm{D}}$ & 95 \\
\hline$\pm \mathrm{SE}$ & 0.875 & 0.914 & 0.011 & 1.680 & 0.009 & 0.523 \\
\hline P-value & 0.0001 & 0.0001 & 0.0001 & 0.0001 & 0.0001 & 0.215 \\
\hline \multicolumn{7}{|c|}{ Male } \\
\hline $\mathrm{T}_{5}$ & $177.7^{\mathrm{C}}$ & $101.7^{c}$ & $1.32^{\mathrm{C}}$ & $133.8^{C}$ & $1.10^{\mathrm{C}}$ & 100 \\
\hline$T_{6}$ & $192.7^{\mathrm{a}}$ & $116.8^{\mathrm{a}}$ & $1.51^{\mathrm{a}}$ & $154.0^{\mathrm{a}}$ & $1.21^{\mathrm{a}}$ & 95 \\
\hline $\mathrm{T}_{7}$ & $183.1^{\mathrm{b}}$ & $107.5^{\mathrm{b}}$ & $1.39^{b}$ & $142.1^{b}$ & $1.14^{\mathrm{b}}$ & 100 \\
\hline $\mathrm{T}_{8}$ & $176.0^{\mathrm{C}}$ & $100.3^{\mathrm{C}}$ & $1.30^{\mathrm{C}}$ & $132.3^{\mathrm{C}}$ & $1.09^{c}$ & 100 \\
\hline $\pm S E$ & 1.422 & 1.40 & 0.018 & 1.845 & 0.009 & 0.334 \\
\hline P-value & 0.0006 & 0.0006 & 0.0006 & 0.0006 & 0.0006 & 0.145 \\
\hline
\end{tabular}

Mean in the same column having different small letters are significantly different $(P \leq$ $0.05)$; FW $(g)=$ Final weight; TWG $(g / f i s h)=[$ Average final weight $(g)-$ Average initial weight (g)]; ADG (g/fish/day) = [TWG (g) / experimental period in days (d)].; RGR = [TWG $(g) /$ Average initial weight $(g)] \times 100$; SGR $(\% /$ day $)=100$ [In final weight - In initial weight] lexperimental period in days (d).; SE: Standard Error. 


\section{Feed and nutrients utilization:}

Data in Table (5) presented feed and nutrients utilization parameters for adult females and males $O$. niloticus. In females and males, the obtained results showed that feed and protein utilization ( $\mathrm{FI}, \mathrm{PER}$ and PPV) had significant improvement $(P \leq 0.05)$ when fed aquafat- ${ }^{\circledR}$ at a level of $1 \%$ compared with the other treatments. In females, $\mathrm{T}_{2}\left(1 \%\right.$ aquafat- $\left.\mathrm{O}^{\circledR}\right)$ was the best values for energy utilization (EU), followed by $\mathrm{T}_{4}\left(3 \%\right.$ aquafat- $\left.{ }^{\circledR}\right)$, and $\mathrm{T}_{3}\left(2 \%\right.$ aquafat- $\left.\mathrm{O}^{\circledR}\right)$ compared with the control group. In males, $\mathrm{T}_{8}(3 \%$ aquafat- ${ }^{\circledR}$ ) gave the highest values in EU among all treatments.

Table (5): Effect of replacing aquafat- $O^{\circledR}$ in the diet on feed and nutrients utilization parameters of the adult Nile tilapia females and males

\begin{tabular}{|l|c|c|c|c|c|}
\hline Treat. & FI (g) & FCR & PER & PPV (\%) & EU (\%) \\
\hline \multicolumn{5}{|c|}{ Female } \\
\hline $\mathrm{T}_{1}$ & $156.6^{\mathrm{c}}$ & $2.58^{\mathrm{a}}$ & $1.16^{\mathrm{c}}$ & $15.42^{\mathrm{b}}$ & $13.31^{\mathrm{b}}$ \\
\hline $\mathrm{T}_{2}$ & $168.7^{\mathrm{a}}$ & $1.95^{\mathrm{c}}$ & $1.55^{\mathrm{a}}$ & $21.85^{\mathrm{a}}$ & $16.71^{\mathrm{a}}$ \\
\hline $\mathrm{T}_{3}$ & $164.0^{\mathrm{b}}$ & $2.20^{\mathrm{b}}$ & $1.37^{\mathrm{b}}$ & $20.34^{\mathrm{a}}$ & $14.93^{\mathrm{ab}}$ \\
\hline $\mathrm{T}_{4}$ & $162.9^{\mathrm{b}}$ & $2.14^{\mathrm{b}}$ & $1.39^{\mathrm{b}}$ & $19.26^{\mathrm{a}}$ & $15.49^{\mathrm{a}}$ \\
\hline \pm SE & 0.574 & 0.027 & 0.016 & 0.742 & 0.516 \\
\hline P-value & 0.0001 & 0.0001 & 0.0001 & 0.011 & 0.047 \\
\hline \multicolumn{7}{|c|}{ Male } \\
\hline $\mathrm{T}_{5}$ & $219.3^{\mathrm{b}}$ & $2.16^{\mathrm{b}}$ & $1.40^{\mathrm{b}}$ & $20.18^{\mathrm{b}}$ & $15.35^{\mathrm{ab}}$ \\
\hline $\mathrm{T}_{6}$ & $225.8^{\mathrm{a}}$ & $1.93^{\mathrm{a}}$ & $1.56^{\mathrm{a}}$ & $23.74^{\mathrm{a}}$ & $14.67^{\mathrm{b}}$ \\
\hline $\mathrm{T}_{7}$ & $224.6^{\mathrm{a}}$ & $2.10^{\mathrm{b}}$ & $1.43^{\mathrm{b}}$ & $20.83^{\mathrm{b}}$ & $14.99^{\mathrm{b}}$ \\
\hline $\mathrm{T}_{8}$ & $210.4^{\mathrm{c}}$ & $2.10^{\mathrm{b}}$ & $1.40^{\mathrm{b}}$ & $20.84^{\mathrm{b}}$ & $16.19^{\mathrm{a}}$ \\
\hline \pm SE & 1.497 & 0.021 & 0.027 & 0.415 & 0.289 \\
\hline $\mathrm{P}$-value & 0.001 & 0.001 & 0.014 & 0.003 & 0.042 \\
\hline
\end{tabular}

Mean in the same column having different small letters are significantly different $(P \leq$ 0.05); FI (g) = Feed intake; FCR = Feed intake (g) $/$ Total weight gain (g).; PER = Total weight gain $(\mathrm{g}) /$ protein intake $(\mathrm{g})$.; PPV $(\%)=100$ [Final fish body protein content $(\mathrm{g})-$ Initial fish body protein content $(\mathrm{g})]$ /crude protein intake $(\mathrm{g})$.; EU $(\%)=($ Retained energy /consumed feed energy) x 100. ; SE: Standard Error.

The whole fish body chemical composition:

The whole fish chemical composition of adult females Nile tilapia at the start at the end of the experimental period is shown in Table (6). Generally, proximate analysis of the whole fish body at the start revealed higher crude protein (CP) than at the end of the experiment, but dry matter (DM), ether extract (EE), ash and energy content (EC) were lower at the start than at the end of the experiment. Results exhibited that the control group had the highest significant $(P \leq 0.05)$ values of $D M$ and ash content compared with the other treatments. While, the $\mathrm{T}_{2}\left(1 \%\right.$ aquafat- $\left.\mathrm{O}^{\circledR}\right)$ gave the best significant $(P \leq 0.05)$ values of $E E$ and $E C$, but it is the lowest values of $D M$ and ash content. Fish fed $1 \%$ aquafat- $O^{\otimes}\left(T_{3}\right)$ had the highest significant $(P \leq 0.05)$ $\mathrm{CP}$, followed by $\mathrm{T}_{2}\left(1 \%\right.$ aquafat- $\left.\mathrm{O}^{\circledR}\right)$, and there is no significant differences $(P$ $\leq 0.05$ ) values between $T_{3}$ and $T_{2}$ in CP. 
Table (6): Effect of replacing aquafat- $\mathrm{O}^{\circledR}$ in the diet on the whole body composition of the adult females Nile tilapia

\begin{tabular}{|l|c|c|c|c|c|}
\hline \multirow{2}{*}{ Treat. } & \multirow{2}{*}{ DM (\%) } & Chemical composition & (\% On dry matter basis) \\
\cline { 3 - 6 } & & CP & EE & Ash & $\begin{array}{c}\text { EC } \\
\text { (Kcal/100 g) }\end{array}$ \\
\hline \multicolumn{5}{|c|}{ At the start: } \\
\hline \multicolumn{6}{|c|}{ At the end: } \\
\hline $\mathrm{T}_{1}$ & 19.67 & 75.53 & 12.41 & 12.06 & 543.1 \\
\hline $\mathrm{T}_{2}$ & $26.16^{\mathrm{a}}$ & $53.53^{\mathrm{C}}$ & $23.26^{\mathrm{b}}$ & $23.23^{\mathrm{a}}$ & $521.5^{\mathrm{C}}$ \\
\hline $\mathrm{T}_{3}$ & $23.66^{\mathrm{D}}$ & $60.86^{\mathrm{a}}$ & $24.90^{\mathrm{a}}$ & $14.23^{\mathrm{C}}$ & $578.5^{\mathrm{a}}$ \\
\hline $\mathrm{T}_{4}$ & $24.17^{\mathrm{b}}$ & $61.30^{\mathrm{a}}$ & $22.80^{\mathrm{b}}$ & $15.93^{\mathrm{b}}$ & $560.9^{\mathrm{b}}$ \\
\hline \pm SE & $24.37^{\mathrm{b}}$ & $58.30^{\mathrm{b}}$ & $24.50^{\mathrm{a}}$ & $17.20^{\mathrm{b}}$ & $560.1^{\mathrm{b}}$ \\
\hline $\mathrm{P}$-value & 0.313 & 0.528 & 0.302 & 0.446 & 2.803 \\
\hline
\end{tabular}

Mean in the same column having different small letters are significantly different $(P \leq$ 0.05); DM: Dry matter (\%); CP: Crude protein (\%); EE: Ether extract (\%); EC: Energy content (Kcal/100 g), calculated according to NRC (1993); SE: Standard Error.

Male:

Results in Table (7) showed that the whole fish composition of the adult males Nile tilapia at the start and the end of the experimental period. Fish fed $1 \%$ aquafat- $\mathrm{O}^{\oplus}\left(\mathrm{T}_{6}\right)$ had the best significant values $(P \leq 0.05)$ of $C P$, but it is the lowest values in DM, EE and ash content. Whereas, the control group $\left(0 \%\right.$ aquafat $\left.-\mathrm{O}^{\circledR}\right)$ recorded the best significant $(P \leq 0.05)$ values in $\mathrm{DM}$ and Ash. There is no significant differences $(P \leq 0.05)$ effect of between $T_{7}$ and $T_{8}$ in DM and CP. Also, fish fed the aquafat- ${ }^{\circledR}$ at levels 1 and $3 \%\left(T_{6}\right.$ and $\mathrm{T}_{8}$, respectively) showed the highest significant $(\mathrm{P} \leq 0.05) \mathrm{EU}$ compared with the control group.

Table (7): Effect of replacing aquafat- $O^{\circledR}$ in the diet on the whole body composition of the adult males Nile tilapia

\begin{tabular}{|l|c|c|c|c|c|}
\hline \multirow{2}{*}{ Treat. } & \multirow{2}{*}{ DM (\%) } & \multicolumn{2}{|c|}{ Chemical composition (\% on dry matter basis) } \\
\cline { 3 - 6 } & & CP & EE & Ash & EC \\
\hline \multicolumn{5}{|c|}{ At the start: } \\
\hline \multicolumn{5}{|c|}{ At the end: } \\
\hline$T_{5}$ & 18.46 & 68.15 & 11.59 & 20.26 & 493.76 \\
\hline $\mathrm{T}_{6}$ & $23.01^{\mathrm{a}}$ & $54.25^{\mathrm{c}}$ & $23.27^{\mathrm{b}}$ & $22.47^{\mathrm{a}}$ & $525.7^{\mathrm{b}}$ \\
\hline $\mathrm{T}_{7}$ & $19.82^{\mathrm{b}}$ & $65.86^{\mathrm{a}}$ & $19.72^{\mathrm{C}}$ & $14.41^{\mathrm{C}}$ & $557.6^{\mathrm{a}}$ \\
\hline $\mathrm{T}_{8}$ & $22.30^{\mathrm{a}}$ & $56.09^{\mathrm{b}}$ & $22.34^{\mathrm{b}}$ & $21.55^{\mathrm{a}}$ & $527.3^{\mathrm{b}}$ \\
\hline \pm SE & $22.05^{\mathrm{a}}$ & $56.85^{\mathrm{b}}$ & $25.29^{\mathrm{a}}$ & $17.84^{\mathrm{b}}$ & $559.5^{\mathrm{a}}$ \\
\hline P-value & 0.440 & 0.0153 & 0.511 & 0.517 & 4.390 \\
\hline
\end{tabular}

a,b,c Mean in the same column having different small letters are significantly different $(P \leq$ 0.05); DM: Dry matter (\%); CP: Crude protein (\%); EE: Ether extract (\%); EC: Energy content (Kcal/100 g), calculated according to NRC (1993); SE: Standard Error.

\section{Economic efficiency:}

Table (8) presents the economic efficiency parameters for the adult females and males $O$. niloticus. The results showed that fish fed $1 \%$ 
aquafat $-\mathrm{O}^{\circledR}$ in females $\mathrm{T}_{2}$ and males $\mathrm{T}_{6}$, respectively had the highest significant $(P \leq 0.05)$ values in total feed costs, total outputs, net return, economic efficiency and relative economic efficiency, compared with the other treatments. Whereas, the control groups fed $0 \%$ aquafat- ${ }^{\circledR}\left(T_{1}\right.$ and $T_{5}$ in female and male, respectively) was the lowest significant $(P \leq 0.05)$ values in economic efficiency parameters. On the other hand, the replacement of aquafat $-O^{\circledR}$ at levels $2 \%$ and $3 \%$ in the diet whether in females or males were higher than the control group. Likewise, there is no significant $(P \leq 0.05)$ differences between the replacement of aquafat- ${ }^{\circledR}$ at levels $2 \%$ and $3 \%$ in the diet whether in females and males in economic efficiency and relative economic efficiency, respectively.

Table (8): Effect of replacing aquafat- $O^{\circledR}$ in the diet on the economic efficiency of adult Nile tilapia females and males

\begin{tabular}{|c|c|c|c|c|c|}
\hline Treat. & $\begin{array}{l}\text { Total feed } \\
\text { costs }^{1}\end{array}$ & $\begin{array}{c}\text { Total } \\
\text { outputs }^{2}\end{array}$ & Net return ${ }^{3}$ & $\begin{array}{l}\text { Economic } \\
\text { efficiency }\end{array}$ & $\begin{array}{c}\text { Relative } \\
\text { economic } \\
\text { efficiency }\end{array}$ \\
\hline \multicolumn{6}{|c|}{ Female } \\
\hline $\mathrm{T}_{1}$ & $16.11^{\mathrm{C}}$ & $15.55^{\mathrm{C}}$ & $0.57^{\mathrm{C}}$ & $3.67^{c}$ & $100.0^{C}$ \\
\hline $\mathrm{T}_{2}$ & $22.43^{\mathrm{a}}$ & $16.60^{\mathrm{a}}$ & $5.82^{a}$ & $35.09^{a}$ & $1015.5^{\mathrm{a}}$ \\
\hline $\mathrm{T}_{3}$ & $19.38^{b}$ & $15.99^{b}$ & $3.38^{b}$ & $21.17^{b}$ & $604.1^{\mathrm{b}}$ \\
\hline $\mathrm{T}_{4}$ & $19.72^{b}$ & $15.74^{\mathrm{C}}$ & $3.98^{D}$ & $25.32^{\mathrm{D}}$ & $743.8^{\text {ab }}$ \\
\hline \pm SE & 0.199 & 0.056 & 0.232 & 1.477 & 86.47 \\
\hline P-value & 0.0001 & 0.0001 & 0.0001 & 0.0001 & 0.001 \\
\hline \multicolumn{6}{|c|}{ Male } \\
\hline $\mathrm{T}_{5}$ & $30.51^{c}$ & $21.77^{\mathrm{a}}$ & $8.73^{\mathrm{C}}$ & $40.11^{\mathrm{C}}$ & $100.0^{C}$ \\
\hline $\mathrm{T}_{6}$ & $35.05^{\mathrm{a}}$ & $22.21^{\mathrm{a}}$ & $12.84^{\mathrm{a}}$ & $57.77^{\mathrm{a}}$ & $144.1^{a}$ \\
\hline $\mathrm{T}_{7}$ & $32.25^{b}$ & $21.89^{\mathrm{a}}$ & $10.36^{b}$ & $47.30^{\circ}$ & $118.3^{b}$ \\
\hline $\mathrm{T}_{8}$ & $30.08^{\mathrm{C}}$ & $20.32^{b}$ & $9.75 b^{c}$ & $48.00^{b}$ & $120.1^{\mathrm{b}}$ \\
\hline \pm SE & 0.420 & 0.146 & 0.293 & 1.100 & 2.741 \\
\hline P-value & 0.0006 & 0.0004 & 0.0003 & 0.0002 & 0.0002 \\
\hline
\end{tabular}

Mean in the same column having different small letters are significantly different $(P \leq$ 0.05).

1. Total outputs per treatment (LE / kg fish) $=$ fish price $\times$ total fish production*

* Total fish production per treatment $=$ final number of fish $\times$ fish weight gain .

2. Total feed costs per treatment $($ LE $/ \mathrm{kg}$ diet $)=$ feed costs per one $\mathrm{kg}$ diet $\times$ feed intake.

3. Net return per treatment $(L E)=$ total outputs - total feed costs .

4. Economic efficiency per treatment $(\%)=($ net return $/$ total feed costs $) \times 100$.

\section{DISSCUSION}

The obtained results in the present study, showed that the positive effects of aquafat- ${ }^{\circledR}$ on the adult females and males Oreochromis niloticus growth performance and feed utilization. It was clear that the replacement of aquafat $-O^{\circledR}$ at level $1 \%$ gave the best values of growth performance and feed utilization parameters in the adult females and males Nile tilapia. The improvement in growth and feed utilization parameters may be attributed to the aquafat- $O^{\circledR}$ replacement which contains fatty acids needed to achieve normal growth of fish. Henderson and Tocher (1987) and (Sargent,1995) have indicated that polyunsaturated fatty acids (PUFA), linoleic acid (LA, 18:2n-6) and linolenic acid (LNA, 18:3n-3), which are also essential fatty 
acids (EFA) for fish, can be converted to these longer chain, more unsaturated, and physiologically important ( HUFAs) by freshwater fish. In addition, Kim et al. (2007) and Aksoy et al. (2009) reported that freshwater fish require dietary sources of polyunsaturated fatty acids of the linoleic and linolenic acid families for optimum growth.

These results were in agreement with, $\mathrm{Ng}$ and Wang (2011), where they proved that the females broodfish fed the linseed oil diet had significantly higher final weight, \% weight gain and specific growth rate than that of fish fed the fish oil + crude palm oil (1: 1) diet. Also, Ali et al. (2000) found that the best body weight gain, specific growth rate, FCR, and PER values were by those fed on diet containing a mixture of all the four dietary lipids (corn oil, olive oil, cod liver oil and beef tallow), compared with each oil only. Also, the diets containing corn oil, olive oil and cod liver oil did not show any significant difference in growth performance of fish.

Moreover, El-Tawil and Amer (2010) indicated that fish oil could be replaced by linseed oil in red tilapia diet without any adverse effect on growth performance or feed efficiency ratio. Also, Singh et al. (2012) found that the mean weight gains and average daily growth feed efficiency and feed conversion ratios were the best in the fish fed the $25 \%$ palm oil $+75 \%$ cod liver diet. Recently, El-Tawil et al. (2014) observed that the highest significant values of FBW, WG, DWG, SGR and FCR were obtained in fish fed at fish oil diet (FO) and mixture of $50 \%$ linseed oil, $25 \%$ corn oil and $25 \%$ soya oil $\mathrm{ML}$ diet (ML) without significant differences between the two treatments. $\mathrm{Ng}$ et al. (2001) found that hybrid tilapia (Oreochromis niloticus $\times$ Oreochromis aureus) fed diets containing vegetable oils as sources of lipid was better in growth performance than fish fed cod liver oil diet. $\mathrm{Ng}$ et al. (2003); Olurin et al. (2004) and Arslan et al. (2008) found the same results with catfish. Likewise, growth of African catfish was significantly $(P<0.05)$ better in fish fed $25 \%$ palm fatty acid distillate (PFAD) diet, compared with fish fed the control diet. Higher levels of dietary PFAD supplementation did not cause further improvement in growth performance of catfish ( $\mathrm{Ng}$ et al., 2004). Also, Chittem and Kunda (2013) indicated that the final body weight, weight gain and specific growth rates (SGR) of Labeo rohita were significantly higher in $1 \%$ omega-3 fatty acid diets than with $3 \%, 5 \%$ and $7 \%$ omega-3 fatty acid. On the other hand, Bahurmiz and $\mathrm{Ng}$ (2007) found that the source of added lipid fish oil, crude palm oil, and palm fatty acid distillate did not significantly influence final body weight, specific growth rate, survival, body indices and production yield of tilapia.

Results in the current study showed that females and males 0 . niloticus fed aquafat $-O^{\circledR}$ by level $1 \%$ led to improvement the chemical composition of whole fish body, where it caused were in an increase of crude protein and decreased of ether extract. These results were in agreement with, El-Tawil et al. (2014) who showed that replacement fish oil by single plant oils or mixed of them in fish diet is more economic and sharply reduced the feed cost. The reduction in feed cost to produce one $\mathrm{kg}$ fish gain in diet containing plant oils was ranged between 23.53 to $28.86 \%$ compared with fish fed at fish oil diet. 
On the other hand, Singh et al. (2012) observed that the muscle proximate compositions did not significantly differ between treatments, similar to earlier findings in tilapia, Oreochromis spp., fed a palm oil based diet (Bahurmiz and $\mathrm{Ng}, 2007$ ). Also, Lim et al. (2008) observed insignificant difference among the moisture, protein and lipid contents of Nile tilapia receiving various dietary lipid sources (fish oil and vegetable oils) diets. ElTawil and Amer (2010) found the same results with red tilapia where no significant differences were observed in fish body moisture or protein contents when fish fed diets containing fish oil or plant oils.

Results in Table 8 showed that the replacement of aquafat- ${ }^{\circledR}$ at levels $1 \%$ in the diets of both females and males Nile tilapia gave the highest values of total feed costs, total outputs, net return, economic efficiency and relative economic efficiency, compared with other treatments. These results agreed with Piedecausa et al. (2007) who noted that consumption of vegetable oils reduced feed costs of seabream. Also, El-Tawil and Amer (2010) found the same results in red tilapia where replacement fish oil by linseed oil reduced oil cost in fish fed more than $87 \%$ without any effect on growth. Montero et al. (2003) reported that fish oils are mostly imported from foreign countries, their price and production figures are dependent upon the wild catch of these oil-yielding species. Steady production and raising prices of fish oil encourage the inclusion of vegetable oils in fish feeds which were more available and economic. As well as, ElTawil et al. (2014) showed that the replacement of fish oil with mixture of plant oils (50\% linseed oil, $25 \%$ corn oil and $25 \%$ soya oil) in the diet of Nile tilapia (Oreochromis niloticus) was more efficient economically, available and sharply reduced the feed cost of Nile tilapia.

Therefore, the obtained results from this study concluded the replacement of aquafat- $O^{\circledR}$ in the diets at level $1 \%$ led to improvement in productive performance and economic efficiency of adult Nile tilapia $O$. niloticus, males and females, so may be using of aquafat- ${ }^{\circledR}$ as growth promoter in fish farming and hatcheries.

\section{Acknowledgment}

The authors are most grateful to Norel-Misr Company, Egypt, for the supply of aquafat- ${ }^{\circledR}$ which are used in the present study.

\section{REFERENCES}

Aksoy, M.Y., C. Lim, R. Shelby, and P. Klesius (2009). Increasing fish oil levels in commercial diets influences hematological and immunological responses of channel catfish, Ictalurus punctatus. Journal of the World Aquaculture Society. 40:76-86.

Ali, A.; Al-Ogaily, S.M.; Al-Asgah, A. N. and Ali, S. (2000). Effect of dietary lipid source on the growth performance and body composition of Oreochromis niloticus. Pakistan Vet. J., 20 (2): 57- 63.

AOAC. (2000). Association of Official Analytical Chemists of official methods of analysis, 17th Ed. Washington, DC. 
Arslan, M.; J. Rinchard, K; Dabrowskii, and M.S. Portella (2008). Effects of Different Dietary Lipid Sources on the Survival, Growth, and Fatty Acid Composition of South American Catfish, Pseudoplatystoma fasciatum, Surubim, Juveniles. Journal of the world aquaculture society. 39: 51-61.

Bahurmiz, O.M. and W.K. Ng (2007). Effects of dietary palm oil source on growth, tissue fatty acid composition and nutrient digestibility of red hybrid tilapia, Oreochromis sp., raised from stocking to marketable size. Aquaculture, 262:382-392.

Bailey,N.T.J.(1995).Statistical methods in biology $3^{\text {rd }}$ edn .The press syndicate of the University of Cambridge, Cambridge,UK.272pp.

Beveridge M.C.M. and McAndrew, B.J. (eds) (2000). Tilapias: biology and exploitation. Kluwer Academic Publisher, Dordrecht

Chittem, P. B. and S. K. Kunda (2013). Effect of dietary omega-3 fatty acid diets on growth and physico-chemical parameters of cultured water in fingerlings of labeo rohita. International Journal of Innovative Research in Science, Engineering and Technology, 2 (8): 3716 - 3722.

Duncan, D.B. (1955). Multiple range and multiple F-test. Biometrics, 11:1-42.

El-Sayed, A.-F.M. (2006). Tilapia Culture (book). CABI Publishing is a division of CAB International, UK. ISBN-13: 978-0-85199-014-9.

El-Tawil N.E. and T.N. Amer. (2010). Effect of different dietary oil sources on fish performance, feed utilization and body composition of Red Tilapia (Oreochromis sp.). fry. Abbasa Int. J. Aqua. Spicial Issue. The third scintefic Conference, Al Azhar Univ,. Cairo 17-18 October 2010. 161177.

El-Tawil, N.E.; Ahmed, M.H.; Amer, T.N. and Seden, M.E. (2014). Effect of replacing dietary fish oil with different plant oils on growth performance of Nile tilapia Oreochromis niloticus. The Journal of Applied Sciences Research. 1(3): 183-191. 2014.

FAO, Food and Agriculture Organization of the United Nations, (2010). The State of World Fisheries and Aquaculture 2010. Rome. 197pp.

GAFRD, (2013). General Authority for Fish Resources Development year book, " Fish Statistics Book in 2013", Ministry of Agriculture and Land Reclamation, Cairo, Egypt, 106 pp.

Henderson, R.J. and D.R. Tocher (1987). The lipid composition and biochemistry of fresh water fish. Progress in Lipid Research. 26:284347.

Izquierdo, M.S., H. Fernandez-Palacios, A.G.J. Tacon (2001). Effect of brood stock nutrition on reproductive performance of fish. Aquaculture, 197: 25-42.

Kim, K.D.; S.M. Lee; H. G. Park; S. Bai and Y.H. Lee (2007). Essentiality of dietary n-3 highly unsaturated fatty acids in juvenile Japanese flounder paralichthys olivaceus. J. of the World Aquaculture Society. 33: 432 440.

Lim, C.; M.Y. Aksoy; A. Davis and P. Klesius (2008). Effects of varied dietary lipid sources tested in tilapia study. Global Aquaculture advocate. June 2008, pp: 67-70. 
Montero, D.; T. Kalinowski; A. Obach; L. Robaina; L. Tort; M.J. Caballero and M.S. Izquierdo (2003). Vegetable lipid sources for gilthead seabream, Sparus aurata: effects on fish health. Aquaculture, 225:252-370.

Ng W.K.; Wang Y.; Ketchimenin P. and K.H. Yuen (2004). Replacement of dietary fish oil with palm fatty acid distillate elevates tocopherol and tocotrienol concentrations and increases oxidative stability in the muscle of African catfish, Clarias gariepinus. Aquaculture, 233:423-437.

$\mathrm{Ng}$, W.K. and Y. Wang (2011). Inclusion of crude palm oil in the broodstock diets of female Nile tilapia, Oreochromis niloticus, resulted in enhanced reproductive performance compared to brood fish fed diets with added fish oil or linseed oil. Aquaculture 314:122-131

Ng, W.K.; P.K. Lim and P. Boey (2003). Dietary lipid and palm oil source affects growth, fatty acid composition and muscle a-tocopherol concentration of African catfish, Clarias gariepinus. Aquaculture. 215: 119-143.

Ng, W.K.; P.K. Lim; and H. Sidek (2001). The influence of a dietary lipid source on growth, muscle fatty acid composition and erythrocyte osmotic fragility of hybrid tilapia. Fish Physiology and Biochemistry. 25:301-310.

NRC (National Research Council) (1993). Nutrient requirements of fish. Committee on Animal Nutrition Board on Agriculture. National Academy Press, ashington DC., USA. 114pp.

Olurin K.B.; Y. Akinyemi; O.Y. Obe and E.A.A. Olojo (2004). Use of palm oil in the diet of the African mudfish, Clarias gariepinus. African Journal of Biotechnology Vol. 3 (8), pp. 418-420.

Pantha, B. (1982). The use of soybean in practical feeds for Tilapia niloticus. M.Sc. Thesis. Univ. of Stirling.

Piedecausa, M.A.; M.J. Mazón; B.G. García and M.D. Hernandez (2007). Effects of total replacement of fish oil by vegetable oils in the diets of sharp snout seabream (Diplodus puntazzo). Aquaculture, 263:211-219.

Sargent, J.R. (1995). Origin and functions of eggs lipids: nutritional implications. In: N.R. Bromage and R.J. Roberts (Eds.), Broodstock Management and Egg and Larval Quality. Blackwell Science, London: 353-372.

SAS (2001). SAS statistical guide for personal computer, SAS Institute Inc. Cary, NC.

Singh, S.K.; M.A. Rather; S.C. Mandal; P. Das; N. Pawar; Y.J. Singh and S.A. Dar (2012). Effects of Dietary Fish Oil Substitution with Palm Oil on Growth, Survival, and Muscle Proximate Composition of Cirrhinus mrigala (Hamilton, 1822). The Israeli Journal of Aquaculture Bamidgeh, IJA_64.2012.809, 5 pages.

Sink, T.D. and Lochmann, R.T. (2008). Effects of dietary lipid source and concentration on channel catfish (Ictalurus punctatus) egg biochemical composition, egg and fry production, and egg and fry quality. Aquaculture, 283(1-4):68-76.

Watanabe, T. (1982). Lipid Nutrition in Fish. Comparative biochemistry and physiology, 73B (1):3-15.

Wootton, R.J. (1990). Ecology of teleost fishes. Chapman \& Hall Ltd , London. 


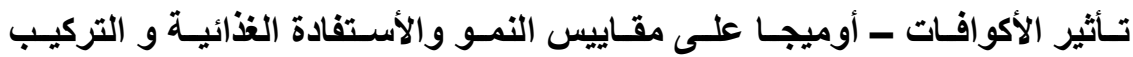

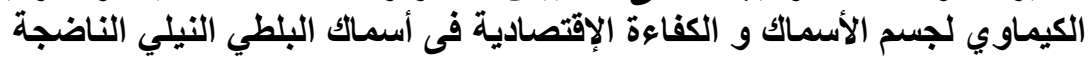

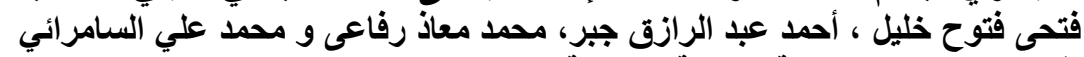

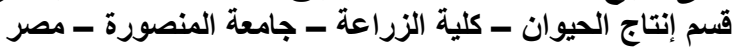

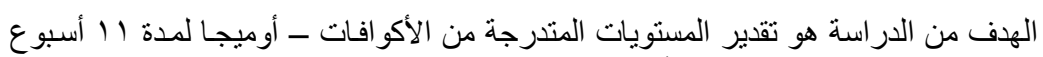

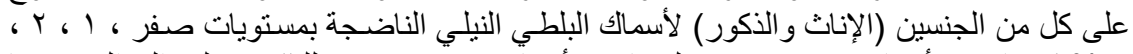

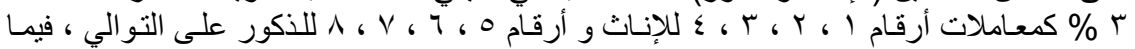

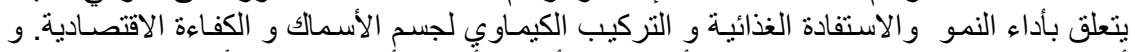

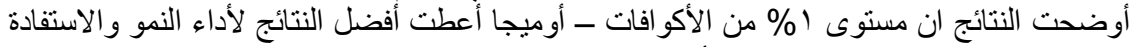

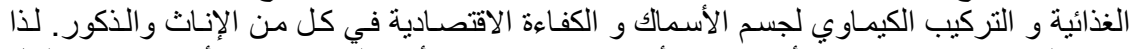

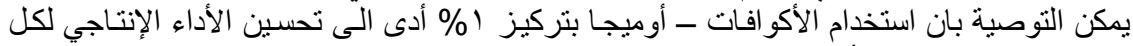
من الإناث و الذكور في أسماك البلطي النيلي الناضجة. 